\title{
Mercury concentrations in blood and feathers of nestling Bald Eagles in coastal and inland Virginia
}

\author{
David E. Kramar ${ }^{1 *}\left(\mathbb{D}\right.$, Bill Carstensen ${ }^{2}$, Steve Prisley ${ }^{3}$ and Jim Campbell ${ }^{2}$
}

\begin{abstract}
Background: Mercury $(\mathrm{Hg})$ and methylmercury are widely considered significant issues for wildlife, and in particular, piscivorous birds due to their widespread availability and neurotoxic properties. Whereas a substantial number of studies of $\mathrm{Hg}$ contamination of Bald Eagles (Haliaeetus leucocephalus) have been conducted throughout the east coast of the United States, little has been done that directly addresses Hg contamination in Bald Eagles in Virginia, particularly the inland population.

Methods: We collected blood and feather samples from nestling Bald Eagles in the coastal plain, piedmont, and western regions of Virginia in an effort to determine which areas of the state were more likely to contain populations showing evidence of $\mathrm{Hg}$ toxicity. We analyzed the samples for total $\mathrm{Hg}$ using a Milestone DMA-80.

Results: Samples collected from individuals located in the coastal region exhibited low concentrations of $\mathrm{Hg}$ compared to those further inland located on freshwater rivers and reservoirs. Samples collected from the inland population exhibited levels in some areas that are approaching what may be considered to be sub-lethal to avian health (blood: mean $0.324 \mathrm{mg} / \mathrm{kg}, \mathrm{SE}=0.13$, range $=0.06-0.97 \mathrm{mg} / \mathrm{kg}$; feather: mean $=8.433 \mathrm{mg} / \mathrm{kg}, \mathrm{SE}=0.3$, range $=3.811-21.14 \mathrm{mg} / \mathrm{kg}$ ).
\end{abstract}

Conclusions: Even after accounting for known point-sources of $\mathrm{Hg}$, the inland eagle population in Virginia is susceptible to concentrations of $\mathrm{Hg}$ that are significantly higher than their coastal counterparts. Moreover, several locations besides those currently known to be impacted by point-sources are exhibiting concentrations that are approaching a sub-lethal level.

Keywords: Bald Eagle, Haliaeetus leucocephalus, Mercury, Methyl-mercury, Virginia

\section{Background}

It is well known that the neurotoxic properties of mercury $(\mathrm{Hg})$ and methylmercury $(\mathrm{MeHg})$ represent a substantial risk to wildlife, in particular, higher trophic level species (Scheuhammer 1987; Yates et al. 2004, 2005; Evers et al. 2005; Hopkins et al. 2013). Wolfe et al. (1998) suggested that the impacts of elevated $\mathrm{Hg}$ are likely more significant when the individuals are in the developmental stages of growth. Moreover, elemental $\mathrm{Hg}$ readily

\footnotetext{
*Correspondence: david.kramar@mnstate.edu

${ }^{1}$ Department of Anthropology and Earth Science, Minnesota State

University Moorhead, 1104 7th Ave S., Moorhead, MN 56563, USA

Full list of author information is available at the end of the article
}

methylates into its more toxic form given appropriate environmental conditions (sulfide and dissolved organic matter) (Miller et al. 2007), making it available to wildlife and humans (Thompson 1996; Evers et al. 2005; Kramar et al. 2005). The widespread transport of $\mathrm{Hg}$ via atmospheric processes, and subsequent atmospheric deposition, ensures that $\mathrm{Hg}$ will remain globally ubiquitous (Wiener et al. 2003). Much of the available $\mathrm{Hg}$ in the atmosphere is due, in large part, to a myriad of industrial sources such as chlor-alkali facilities (Maserti and Ferrara 1991), as well as the continued combustion of coal and other fossil fuels (Berlin et al. 2007). Due to extensive risks posed to humans and wildlife from the 
accumulation of $\mathrm{Hg}$, every state within the continental US has fish consumption advisories already in place.

Research on $\mathrm{Hg}$ in Bald Eagles (Haliaeetus leucocephalus) has been conducted in numerous eastern states including South Carolina (Jagoe et al. 2002), Florida (Wood et al. 1996), Maine (Welch 1994), New York (DeSorbo et al. 2008, 2009), and the Great Lakes region of the US (Bowerman et al. 1994). Although the Bald Eagle has been studied extensively in the Coastal Plain of Virginia (Buehler 1990; Buehler et al. 1991; Watts et al. 2011), little research on Bald Eagles has been conducted in the inland regions, due in part to a lack of knowledge of the inland distribution. Wiemeyer et al. (1984) analyzed nonviable eggs from Bald Eagles in the Chesapeake Bay, and reported concentrations of $\mathrm{Hg}$ between 0.03 and $0.17 \mathrm{mg} /$ $\mathrm{kg}$, and Cristol et al. (2012) found that eagles residing near the Chesapeake Bay exhibited low concentrations of $\mathrm{Hg}$ in molted feathers. In contrast to the Chesapeake Bay, several inland areas in the state have been identified as hotspots for $\mathrm{Hg}$ exposure to other avian species, including the Shenandoah River (Jackson et al. 2011; Cristol et al. 2012; Hopkins et al. 2013) and the North Fork of the Holsten River (Echols et al. 2009). Jackson et al. (2011) noted that forest songbirds were exhibiting elevated $\mathrm{Hg}$ concentrations over $130 \mathrm{~km}$ downstream of the known point source on the Shenandoah River, with $\mathrm{Hg}$ distributed in downstream habitat features such as flood plain areas.

Within the state of Virginia, the majority of the known eagle population ( $n=726$ occupied territories 2011) nests within the coastal plain associated with the Chesapeake Bay and the major tributaries that feed the bay (Watts et al. 2011). However, more than $25 \%$ of the total population $(n>200)$ nests in the Piedmont and Mountain regions (Kramar D., unpublished data). Prior to 2007, little information regarding the inland population was available. As elevated $\mathrm{Hg}$ in wildlife has been positively associated with freshwater environments, we expect that $\mathrm{Hg}$ concentrations in central and western Virginia eagles would exhibit significantly higher levels in blood and feather than those of the coastal plain. Moreover, as $\mathrm{Hg}$ accumulates in the body with age (Kamman et al. 2005), nestling eagles that are expressing levels at or above those considered sub-lethal are an important indicator of $\mathrm{Hg}$ in the immature and adult cohorts of the same eagle population.

Our objectives were to establish reference levels for $\mathrm{Hg}$ contaminants in Bald Eagles in coastal Virginia based on previous work (Cristol et al. 2012) and from collection and analysis of new tissue samples from nestling Bald Eagles. This allowed us to test our hypothesis that inland $\mathrm{Hg}$ concentrations were significantly higher than the Hg concentrations found in Bald Eagles in the coastal population. We also evaluated the spatial variability of $\mathrm{Hg}$ across the inland population, and analyzed the relationship between blood $\mathrm{Hg}$ and feather $\mathrm{Hg}$.

\section{Methods \\ Study area and surveys}

We conducted this throughout the state of Virginia between the spring of 2007 and the spring of 2012. The population of eagles in Virginia has rebounded from a low of approximately 80 pairs in the 1970s (Abbott 1978), to over 800 by 2012 for both the coastal and inland populations (Watts et al. 2011; Kramar D., unpublished data). We sampled 28 nests across the state, and 46 individuals (Fig. 1). In instances where there were multiple individuals per nest, we used the average $\mathrm{Hg}$ concentration between the individuals to represent the $\mathrm{Hg}$ concentration per nest. We also checked to see if using either the minimum or maximum values had any effect on the resulting models. Coastal nests were defined as those that fell within the coastal plain (east of the fault line), and inland nests were defined as those that fell within the Piedmont and Mountain physiographic regions (west of the fault line). Nests were randomly selected and assessed for climbability based on the condition of the tree, and the age of the individuals. In a small number of cases, selected nests could not be climbed due to lack of approval from the property owner. In these cases, we selected another nest.

\section{Blood and feather collection}

We collected samples from 4 to 7 week old eaglets by climbing to the nests and lowering them to the ground in a protective bag. We collected blood samples from the brachial vein in the wing using 21 gauge butterfly needles and $4 \mathrm{cc}$ lithium heparinized vacutainers. Each vacutainer was labeled with a unique nest identification number and the federal band number, and the blood was packed on ice and frozen within $4 \mathrm{~h}$ of collection. We collected two to three contour feathers from the breast of each individual. The samples were placed in a brown envelope, sealed, and labeled with the nest identification number and federal band number. All activities were conducted under the appropriate state and federal permits.

\section{Blood and feather analysis}

Samples were analyzed using a Milestone DMA-80 Direct Mercury Analyzer (DMA) at the Sawyer Environmental Research Center, located at the University of Maine, Orono. Analysis of samples was conducted after calibrating the DMA using a certified standard Hg solution (SPEX CertiPrep) (Cell 1: $R^{2}=1.0000$, Cell 2: $\left.R^{2}=0.9998\right)$. All calibration and sampling consisted of measuring both the SPEX and the samples 


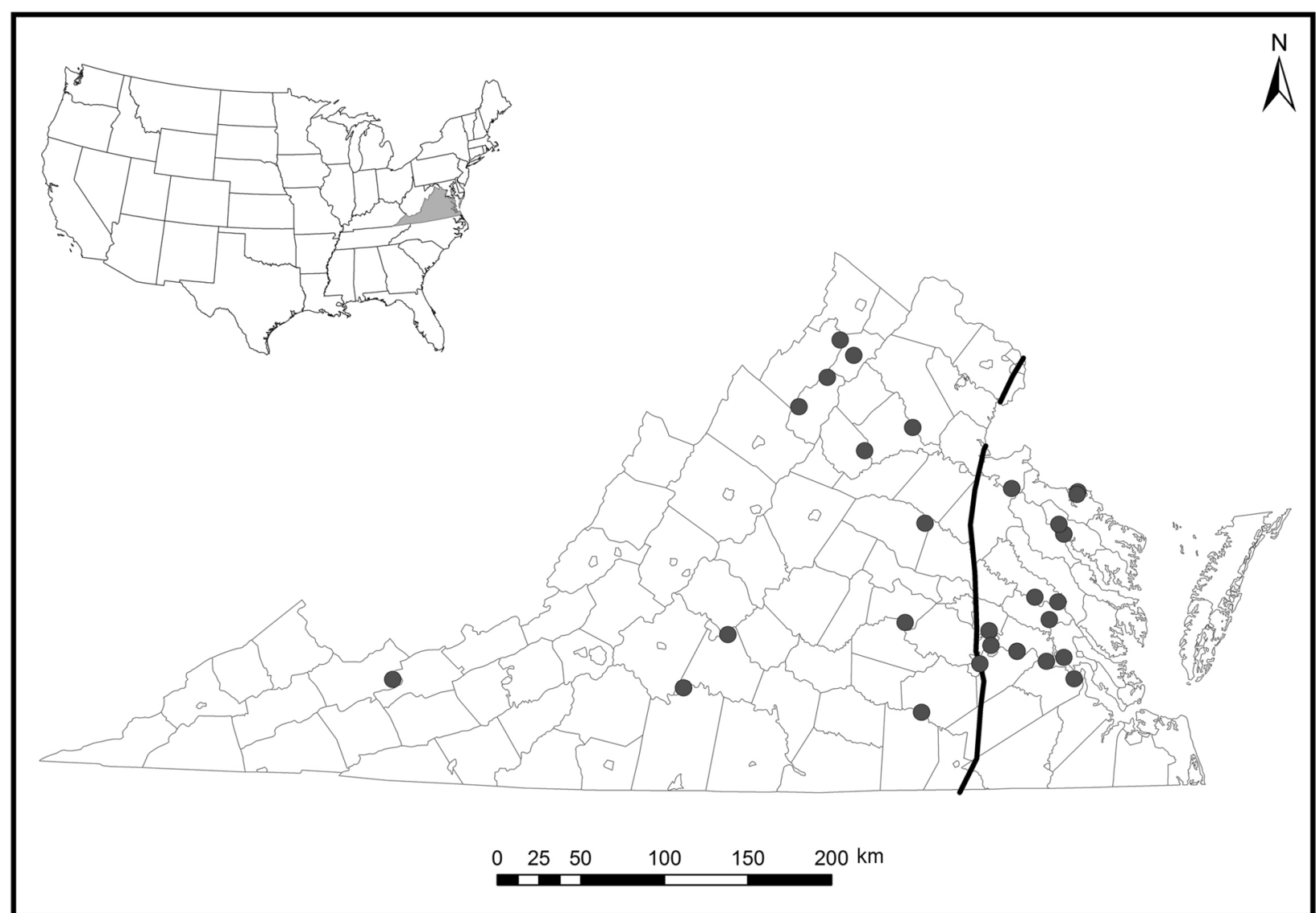

Fig. 1 Study area and sample locations where Hg concentrations were sampled in Bald Eagles, 2007-2012. Sample locations are represented by the gray circles. The break between the coastal plain and the inland regions of the state is defined by the black line. Areas west of the fault line are considered "inland", while areas east of the fault line are considered "coastal"

to the nearest $0.0001 \mathrm{~g}$ using a Metler Toledo digital scale, Model AT201). Quality assurance measures included the use of standard reference materials. In addition to the standard reference materials, two system and method blanks, one 10-ng prepared Spex sample, one 60-ng prepared Spex sample, one replicate, and one matrix spike were run as quality assurance per every ten biological samples. Feathers were mechanically washed following Ackerman et al. (2007) in a $1 \%$ Alconox solution, rinsed 6 times in deionized water, and dried for 24-48 h. The recovery of standard reference materials was near $100 \%$ and well within the accepted range of $90-110 \%$. QC verification was $105.6 \%$ and $103.1 \%$ during calibration. Similarly, replicate samples were well within accepted parameters. Spiked samples were based on the addition of $0.05 \mathrm{~g}$ of $10 \mathrm{ng}$ SPEX. Once prepared, samples were weighed out and placed in quartz or nickel boats for analysis (depending on the matrix type: quartz $=$ blood, nickel $=$ feather). No more than 20 samples were analyzed at any one time, with QC procedures conducted following every ten samples. Analysis generally followed US Environmental Protection Agency Method 7473 (USEPA 2000).

\section{Statistical analysis}

We conducted a power analysis both prior to collection of samples and post sampling, to insure that the sample size was adequate to make inferences regarding the population. Given a standard deviation across all samples of 0.205 , and 28 samples (individual nests), the power to determine differences between the coastal and inland populations at $\alpha=0.25$ was 0.874 .

We initially log-transformed the $\mathrm{Hg}$ scores and applied the Shapiro Wilks Goodness of Fit test to determine whether they met normality requirements. Because the log-transformed data did not approximate a normal distribution, we compared the $\mathrm{Hg}$ in coastal and inland populations using the non-parametric 
Wilcoxon test. To determine the effect of point contaminant sources on the Shenandoah River, we ran a second Wilcoxon test while withholding the data from the Shenandoah River.

To test for a relationship between blood $\mathrm{Hg}$ and feather $\mathrm{Hg}$, we developed a predictive model of the function. We initially fit a linear regression model and evaluated the fit by analyzing the residual distribution. Due to the non-linear nature of our sample distribution we utilized a non-linear quadratic regression to appropriately model the relationship.

\section{Results}

The mean blood $\mathrm{Hg}$ concentration across Virginia eagles was $\bar{x}=0.180 \mathrm{mg} / \mathrm{kg}, \mathrm{SE}=0.036$. The mean concentration for feather $\mathrm{Hg}$ was $\bar{x}=5.024 \mathrm{mg} / \mathrm{kg}, \mathrm{SE}=0.842$. The lowest blood $\mathrm{Hg}$ concentrations sampled $(0.012 \mathrm{mg} / \mathrm{kg}$, $\mathrm{SE}=0.012$ ) were located in birds from the coastal plain of Virginia, specifically on the Pamunkey River. The highest concentrations were sampled in birds located inland on the Shenandoah River, in particular on the South Fork of the Shenandoah River $(0.974 \mathrm{mg} / \mathrm{kg}, \mathrm{SE}=0.065)$.

Blood $\mathrm{Hg}$ concentrations in the coastal plain $(\bar{x}=0.06 \mathrm{mg} / \mathrm{kg}, \quad \mathrm{SE}=0.012 \mathrm{mg} / \mathrm{kg}, \quad$ range $=0.01-$ $0.15 \mathrm{mg} / \mathrm{kg})$ were significantly less $(Z=4.676, p<0.0001$, $\left.x^{2}=21.96, p<0.0001\right)$ than blood $\mathrm{Hg}$ concentrations in inland nests $(\bar{x}=0.324 \mathrm{mg} / \mathrm{kg}, \mathrm{SE}=0.065 \mathrm{mg} / \mathrm{kg}$, range $=0.06-0.97 \mathrm{mg} / \mathrm{kg}$ ). Feather $\mathrm{Hg}$ concentrations in the coastal plain $(\bar{x}=2.16 \mathrm{mg} / \mathrm{kg}, \mathrm{SE}=0.420 \mathrm{mg} /$ $\mathrm{kg}$, range $=0.62-9.998 \mathrm{mg} / \mathrm{kg}$ ) were significantly less $\left(Z=4.168, \quad p<0.0001, \quad x^{2}=17.465, \quad p \leq 0.0001\right)$ than feather $\mathrm{Hg}$ concentrations in inland nests $(\bar{x}=8.43 \mathrm{mg} /$ $\mathrm{kg}, \mathrm{SE}=1.47$, range $=3.81-21.14 \mathrm{mg} / \mathrm{kg}$ ). After removing the Shenandoah River from the analysis, we still found that the coastal blood $\mathrm{Hg}$ concentrations were significantly less $\left(Z=4.0, p<0.0001, \chi^{2}=16.08, p<0.0001\right)$ than blood $\mathrm{Hg}$ concentrations in the inland nests. Likewise, after removing the Shenandoah River from the analysis, feather $\mathrm{Hg}$ concentrations from the coastal plain were significantly less $\left(Z=3.38, p=0.0007, \chi^{2}=11.52\right.$, $p=0.0007)$ than feather $\mathrm{Hg}$ concentrations from the inland nests.

The quadratic regression model provided the best overall fit to our data (Fig. 2). This cumulative function (Fig. 2) supported the prediction that $\mathrm{Hg}$ in feathers accumulated over time, representing total body burden, while $\mathrm{Hg}$ in blood represented recent dietary uptake. In that respect, the relationship between feather and blood

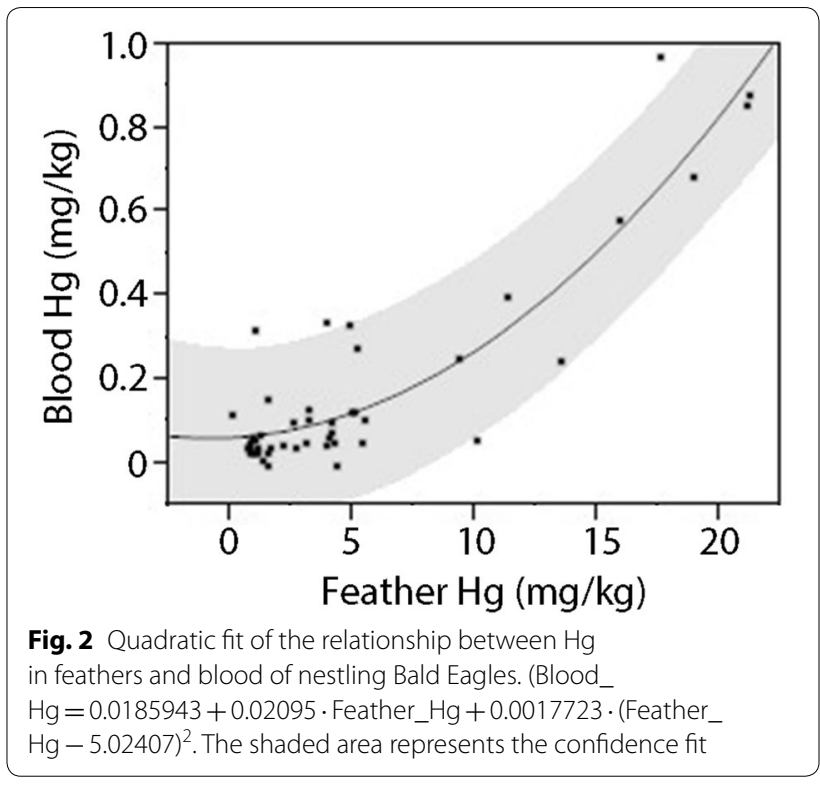

$\mathrm{Hg}$, in this study, is a cumulative function. The analysis of variance table indicated a sufficient model fit $(F=12.97$, $\mathrm{df}=1, \mathrm{SS}=0.133, p=0.001)$ that represents $83.4 \%$ of the variance of blood $\mathrm{Hg}$ concentrations.

\section{Discussion}

While we found that the coastal population of nestling Bald Eagles in Virginia had Hg concentrations that are not of a level currently of concern, the inland population has $\mathrm{Hg}$ burdens that are at significantly higher concentrations than previously expected. These findings support Cristol et al. (2012) who also documented low levels of $\mathrm{Hg}$ in Bald Eagles in coastal Virginia. To establish a threshold for what may be considered sub-lethal concentrations of $\mathrm{Hg}$, we used a blood $\mathrm{Hg}$ concentration of $0.70 \mathrm{mg} / \mathrm{kg}$ (Desorbo and Evers 2007). Whereas Bald Eagles along several inland rivers exhibited blood $\mathrm{Hg}$ levels approaching that threshold, only the Shenandoah River exceeded it (Fig. 3). No eagles along rivers in coastal Virginia approached this threshold. Specifically, rivers where eagles exhibited elevated concentrations include the inland portions of the Rappahannock River, Nottoway River, James River, and Wolf Creek. The higher concentrations of feather $\mathrm{Hg}$ found in this study, not surprisingly, follow patterns similar to that of the blood $\mathrm{Hg}$ concentrations (Fig. 4).

Given that $\mathrm{Hg}$ is sequestered rapidly during feather growth, it is not unreasonable to expect that once 


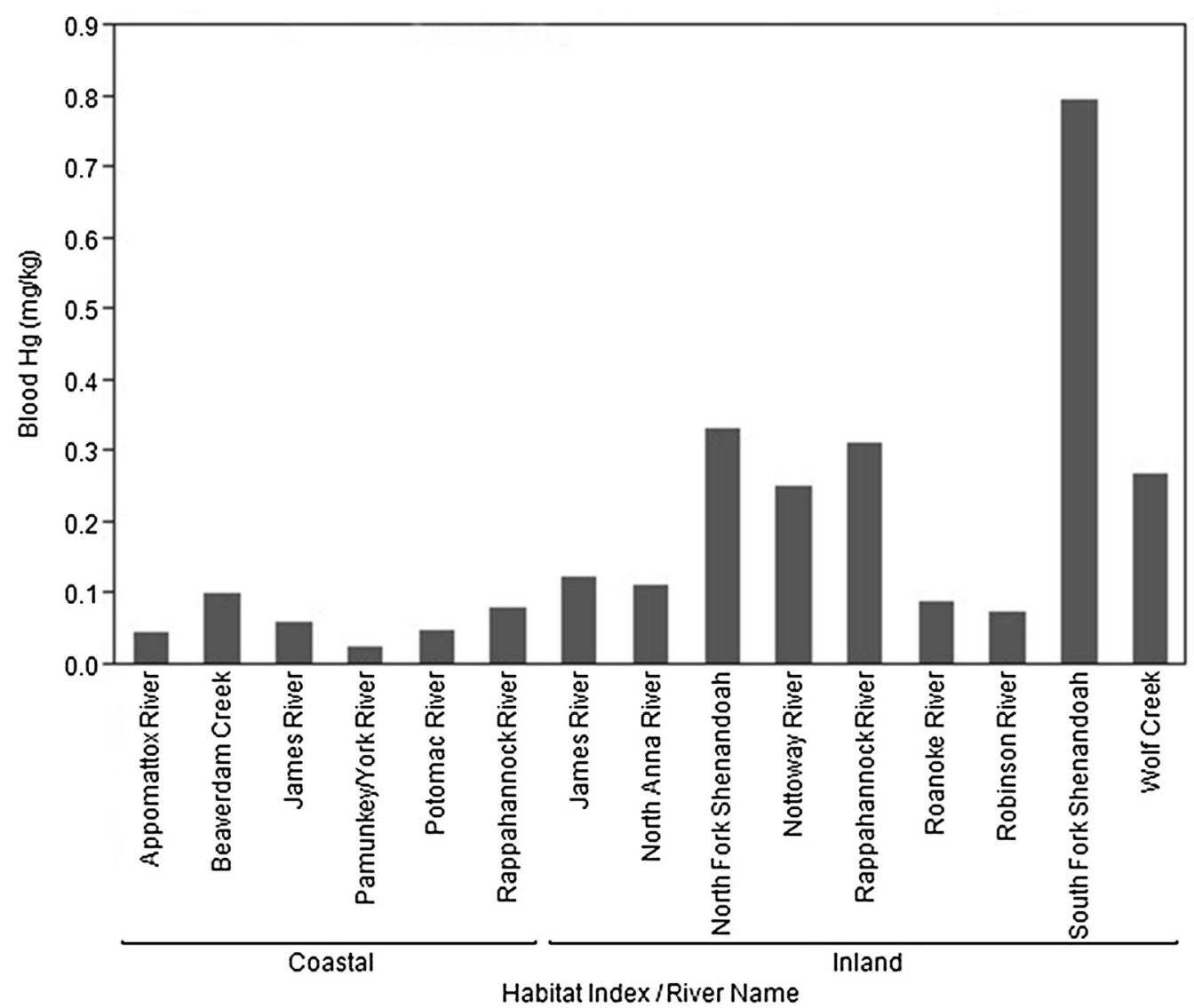

Fig. 3 Mean blood $\mathrm{Hg}$ concentrations ( $\mathrm{mg} / \mathrm{kg}$ ) in nestling Bald Eagles by river and habitat type in Virginia

feather development is complete, levels of blood $\mathrm{Hg}$ would increase. Condon and Cristol (2009) suggest that the most likely period for $\mathrm{Hg}$ to approach sub-lethal levels is immediately following fledging, when feathers are no longer sequestering $\mathrm{Hg}$ from the blood. Thus an individual at 4 weeks of age, which is approaching a $0.70 \mathrm{mg} / \mathrm{kg}$ threshold, would likely exceed that threshold once the feathers have completely developed. This relationship between blood $\mathrm{Hg}$ and feather growth in Bald Eagles identifies the need for additional sampling of adult Bald Eagles in inland Virginia. Moreover, additional research should be conducted on the North Fork of the Shenandoah River as $\mathrm{Hg}$ concentrations here were also approaching the $0.70 \mathrm{mg} / \mathrm{kg}$ threshold.

\section{Conclusions}

Inland eagle populations within Virginia are exposed to a greater amount of $\mathrm{Hg}$ than their coastal counterparts. This variation in $\mathrm{Hg}$ concentrations is likely due to a number of different factors. First, $\mathrm{Hg}$ methylates more readily in freshwater environments, and as such, that $\mathrm{Hg}$ would be available to wildlife that reside there. Second, we speculate that the elevated concentrations of $\mathrm{Hg}$ in inland eagle populations are also influenced by the variation in potential prey between the freshwater and saline environments. Because of these factors, the freshwater environment of the Piedmont and Mountain regions warrants continued monitoring to understand the longterm implications of $\mathrm{Hg}$ in these areas. In particular, additional work along the Nottoway River, Holsten River, 


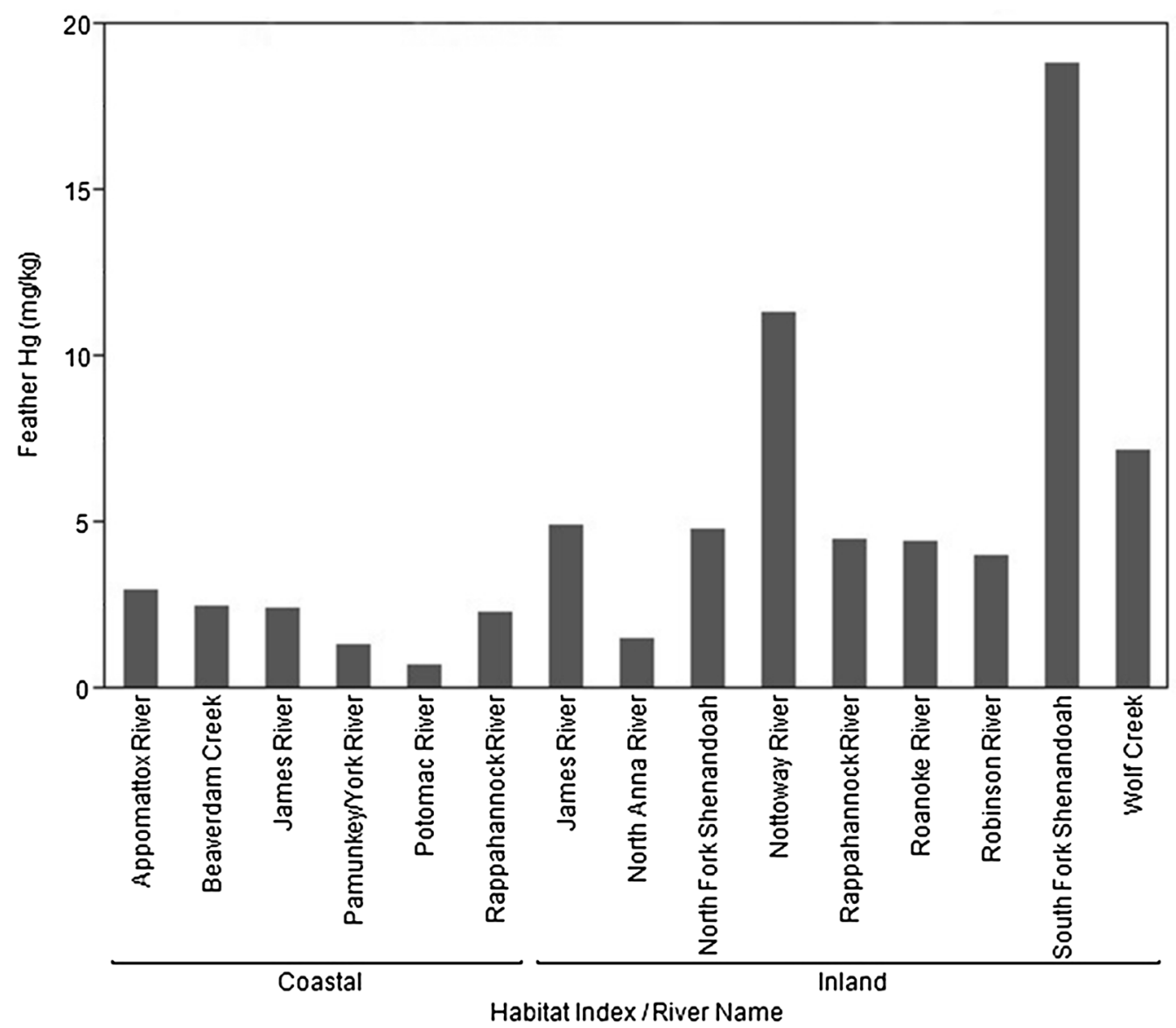

Fig. 4 Mean feather Hg concentrations $(\mathrm{mg} / \mathrm{kg}$ ) in nestling Bald Eagles by river and habitat type in Virginia

Shenandoah River, Rappahannock River, and Wolf Creek should be conducted.

From a management perspective, additional efforts to facilitate remediation and further understand the full distribution and potential implications of $\mathrm{Hg}$ within the inland portions of the state should be considered. These efforts should include research into potential point sources on the above mentioned rivers, as well as further research into the $\mathrm{Hg}$ concentrations in adult Bald Eagles. Lastly, given the $\mathrm{Hg}$ concentrations found on the rivers sampled in this research, additional efforts should be focused on sampling rivers that were not represented such as the Powell River, the Holston River, and the New River.

\section{Authors' contributions}

DEK collected and analyzed the data associated with this work. BC aided in editorial suggestions, geospatial analysis, and presentation of material. SP assisted in analysis, editorial suggestions, and geospatial analysis. JC assisted in editorial comments and statistical analysis. All authors read and approved the final manuscript.

\section{Author details}

${ }^{1}$ Department of Anthropology and Earth Science, Minnesota State University Moorhead, 1104 7th Ave S., Moorhead, MN 56563, USA. ${ }^{2}$ Department of Geography, Virginia Tech, 115 Major Williams Hall, Blacksburg, VA 24061, USA. ${ }^{3}$ National Council for Air and Stream Improvement, 541 Washington Ave SW, Roanoke, VA 24016, USA.

\section{Acknowledgements}

We would like to extend our sincere gratitude to the Virginia Department of Game and Inland Fisheries: specifically Sergio Harding and Jeff Cooper. In addition, we would like to thank the staff at the Wildlife Center of Virginia, Bryan Watts and Libby Mojica from the University of William and Mary, and Justin Miller, Kari McMullen, Emily Wright, and Jessica Rich for extensive field assistance. Samples were collected under federal permits held by the University of William and Mary (Dr. Bryan Watts) or the Virginia Dept. of Game and Inland Fisheries (Jeff Cooper), and state threatened and endangered species permits. IACUC approval was acquired through the Virginia Tech Institutional Animal Care and Use Committee.

\section{Competing interests}

The authors declare they have no competing interests.

\section{Availability of data and materials}

The datasets generated during and/or analyzed during this study are available from the corresponding author on reasonable request.

\section{Consent for publication}

Not applicable. 


\section{Ethics approval and consent to participate}

IACUC approval was secured through Virginia Polytechnic Institute and State University for the duration of the project.

\section{Funding}

Funding for this research was supported under the US Environmental Protection Agency — Science to Acheive Results (STAR) Fellowship Program \# F6C20816 and the Virginia Dept. of Game and Inland Fisheries.

Received: 5 April 2018 Accepted: 14 January 2019

Published online: 19 January 2019

\section{References}

Abbott JM. Chesapeake Bay Bald Eagles. Delaware Conserv. 1978;22:3-9.

Ackerman JT, Eagles-Smith CA, Takekawa JY, Bluso JD, Adelsbach TL. Mercury concentrations in blood and feathers of prebreeding Forster's Terns in relation to space use of San Francisco Bay California, USA habitats. Environ Toxicol Chem. 2007;27:897-908.

Berlin M, Zalups RK, Fowler BA. Mercury. In: Nordberg GF, Fowler BA, Nordberg M, Friberg LT, editors. Handbook on the toxicology of metals. 3rd ed. Amsterdam: Elsevier; 2007. p. 675-729.

Bowerman WW, Evans ED, Geisy JP, Postupalsky S. Using feathers to assess risk of mercury and selenium to bald eagle reproduction in the Great Lakes region. Arch Environ Contam Toxicol. 1994;27:294-8.

Buehler DA, Mersmann TJ, Fraser JD. Differences in distribution of breeding, nonbreeding, and migrant Bald Eagles on the northern Chesapeake Bay. Condor. 1991;93:399-408.

Buehler DA. Bald eagle distribution, abundance, roost use, and response to human activity on the northern Chesapeake Bay, Maryland. PhD Thesis. Blacksburg: Virginia Polytechnic Institute and State University; 1990.

Cristol DA, Mojica EK, Varian-Ramos CW, Watts BD. Molted feathers indicate low mercury in Bald Eagles of the Chesapeake Bay, USA. Ecol Indic. 2012;18:20-4.

Condon AM, Cristol DA. Feather growth influences blood mercury level of young songbirds. Environ Toxicol Chem. 2009;28:395-401.

Desorbo CR, Evers DC. Evaluating exposure of Maine's Bald Eagle population to mercury: assessing impacts on productivity and spatial exposure pat terns. Unpublished Report. BRI 2007-02. Gorham: BioDiversity Research Institute; 2007.

DeSorbo CR, Evers DC, Nye PE, Loukmas JJ. Assessing mercury exposure and spatial patterns in adult and nestling bald eagles in New York State, with an emphasis on the Catskill Region. Report BRI 2008-06 Submitted to The Nature Conservancy, Albany, New York. Gorham: BioDiversity Research Institute; 2008.

Desorbo CR, Todd CS, Mierzykowski SE, Evers DC, Hanson B. Assessment of mercury in Maine's interior bald eagle population. USFWS. Spec. Proj. Rep. FY07-MEFO-3-EC. Old Town: Maine Field Office; 2009.

Echols BS, Currie RJ, Cherry DS. An investigation of total mercury in sediments and interstitial water in the North Fork Holsten River below Saltville, VA, USA. Hum Ecol Risk Assess. 2009;15:968-84.

Evers DC, Burgess N, Champoux L, Hoskins B, Major A, Goodale W, Taylor R, Poppenga R, Daigle T. Patterns and interpretation of mercury exposure in freshwater avian communities in northeastern North America. Ecotoxicology. 2005;14:193-221.

Hopkins BC, Willson JD, Hopkins WA. Mercury exposure is associated with negative effects on turtle reproduction. Environ Sci Technol. 2013;47:2416-22.
Jackson AK, Evers DC, Etterson MA, Condon AM, Folsom SB, Detweiler J, Schmerfeld J, Cristol DA. Modeling the effect of mercury exposure on the reproductive success of a free-living terrestrial songbird, the Carolina Wren (Thyrothorus ludovicianus). Auk. 2011;128:1-11.

Jagoe C, Bryan AL, Brant HA, Murphy TM, Brisbin IL. Mercury in bald eagle nestlings from South Carolina, USA. J Wildl Dis. 2002;38:706-12.

Kamman NC, Burgess NM, Driscoll CT, Simonin HA, Goodale W, Linehan J, Estabrook R, Hutcheson M, Major A, Scheuhammer AM, Scruton DA. Mercury in freshwater fish of northeast North America-a geographic perspective based on fish tissue monitoring databases. Ecotoxicology. 2005; 14:163-80.

Kramar DE, Goodale W, Kennedy L, Carstensen LW, Kaur T. Relating land cover characteristics and Common Loon mercury levels using geographic information systems. Ecotoxicology. 2005;14:253-62.

Maserti BE, Ferrara R. Mercury in soils, plants and atmosphere near a chloralkali complex. Water Air Soil Pollut. 1991;56:15-20.

Miller CL, Mason RP, Gilmour CC, Heyes A. Influence of dissolved organic matter on the complexation of mercury under sulfidic conditions. Environ Toxicol Chem. 2007;26:624-33.

Scheuhammer AM. The chronic toxicity of aluminum, cadmium, mercury, and lead in birds: a review. Environ Pollut. 1987;46:263-95.

Thompson DR. Mercury in birds and terrestrial animals. In: Beyer WN, Heinz GH, Redmon-Norwood AW, editors. Environmental contaminants in wildlife: interpreting tissue concentrations. Clemson: Lewis Publisher; 1996. p. 341-55.

US Environmental Protection Agency. Method 7473: mercury in solids and solutions by thermal decomposition, amalgamation and atomic absorption spectrometry. United States Environmental Protection Agency; 2000.

Watts BD, Byrd MA. Virginia bald eagle nest and productivity survey: year 2011 report. Center for Conservation Biology Technical Report Series, CCBTR11-11. Williamsburg: College of William and Mary and Virginia Commonwealth University; 2011.

Welch LJ. Contaminant burdens and reproductive rates of Bald Eagles in Maine. MS thesis. Orono: University of Maine; 1994.

Wiemeyer SN, Lamont TG, Bunck CM, Sindelar CR, Gramlich FJ, Fraser JD, Byrd MA. Organochlorine pesticide, PCB, and Mercury residues in bald eagle eggs, 1969-1979, and their relationships to shell thinning and reproduction. Arch Environ Contam Toxicol. 1984;13:529-49.

Wiener JG, Krabbenhoft DP, Heinz GH, Scheuhammer AM. Ecotoxicology of mercury. In: Hoffman DJ, Rattner BA, Burton Jr GA, Cairns Jr J, editors. Handbook of ecotoxicology. 2nd ed. Boca Raton: CRC Press; 2003. p. 409-63.

Wolfe MF, Schwarzbach S, Sulaiman RA. Effects of mercury on wildlife: a comprehensive review. Environ Toxicol Chem. 1998;17:146-60.

Wood PB, White JH, Steffer A, Wood JM, Facemire CF, Percival HF. Mercury concentrations in tissues of Florida Bald Eagles. J Wildl Manag. 1996:60:178-85.

Yates D, Evers DC, Savoy L. Developing a mercury exposure profile for mink and river otter in Maine. Report BRI 2004-09 submitted to Maine Department of Environmental Protection and Maine Inland Fisheries and Wildlife. Gorham, Maine: BioDiversity Research Institute; 2004.

Yates D, Mayack D, Munney K, Evers DC, Taylor RJ, Kaur T, Major A. Mercury levels in mink and river otter in northeastern North America. Ecotoxicology. 2005;14:263-74. 